\title{
Trouble in Paradise
}

\section{Misbehaviour and Disbelief in The Isle of Pines}

\section{SAM GILCHRIST HALL}

Abstract: Viewing utopias and histories as two sides of the same fantasy enables an interpretation of Henry Neville's The Isle of Pines (1668) that reads it as both a caustic commentary on the problems inherent in monarchical government - especially when an absolute sovereign is dissolute - and a profoundly self-critical utopia. It is primarily through its complex and, at times, parodic intertextuality with Exodus that this text offers an ironic commentary on the notion of paradise itself, a beguiling no-place, located in the dimmest recesses of the past, which continues to inspire blueprints for a better world.

\section{History and Utopia in Exodus}

"Utopia too must have a history."

(H. G. Wells)

At first glance, the connection between histories, commonly considered to be factual accounts about what actually happened, and utopias, fantastical fictions about what could come to be in a no-place (оvтолía), seems tenuous at best. On closer inspection, however, they are not without some common ground. Utopias are commonly modelled on the ur-fantasy of an ideal state in the distant past - a Golden Age in a paradise, where, as Kurt Vonnegut put it, "everything was beautiful and nothing hurt" (155) - and writing history also involves, if not active nostalgia, then at the very least an envisaging of a place and time other than the one in which we now find ourselves. Furthermore, it is surely more than a coincidence that this seemingly paradoxical relationship is clearly identifiable in Exodus, which - as memory and 
a promise, history and utopia - is a progenitor of both historical and utopian writing, recording as it does the Israelites' flight from Egypt, the story of Passover and the revelation of Mosaic Law, while promising their eventual inhabitation of "a land flowing with milk and honey" ( $K \mathcal{J} V$, Exodus 13.5), free from foreign oppression and, crucially, people of other races and faiths.

Furthermore, as an unequivocal act of historical self-assertion, Exodus founds Israel. Justifying the actions of the present by recourse to hereditary privilege, like most early modern - and, indeed, a considerable number of modern - histories, it opens with a clear assertion of historical precedence; the Israelites were in Egypt long before the current Pharaoh came to power: "And all the souls that came out of the loins of Jacob were seventy souls: for Joseph was in Egypt already" (KJV, Exodus 1.6). Whether one takes its events metaphorically or literally, Exodus clearly offers the history of a sort, but it can also be considered as a utopian text. Not only does it depict a Promised Land but also - more importantly for the purposes of this article - it is the originary text of the Law. And although it may seem obvious that an ideal state would not need any laws, it is basically impossible to design a practicable society without them. Indeed, presumably for this reason, utopias are characterised by a preoccupation with legislation and prohibition, which distinguishes them in the strict sense from "the other four models of an ideal society . . Abundantia, Moralia, Millennium and Naturalia" (Avilés 225); "utopianism," argues J. C. Davis, is "primarily concerned with institutional perfection. An improvement in the moral behaviour of man may be seen as resulting from this but man's moral perfection is not a prior assumption" (174). Thus, Ralph Robinson's 1551 English translation of More's Utopia bills its Second Book as "containing the description of Utopia, with a large declaration of . . . all the good laws and orders of the same island" (Bruce 49). ${ }^{1}$ Paradoxical as it may seem, early modern utopias are more concerned with legal reform than with simply "dreaming on things to come" (Shakespeare, Sonnet 107.2).

Leaving aside, for the moment, the remarkable formal affinities between early modern utopias and Exodus - most notably, their shared predilection for genealogies and lists of prohibitions, to which we shall return - the content of utopian texts from this era seems to be inspired, implicitly and explicitly, by this biblical narrative in particular. In his 1652 pamphlet, The Law of Freedom on a Platform; or, True Majesty Restored,

1 The A and B texts of the original read simply: "Raphaelis Hythlodei sermo de optimo Reip. statu, per Thomam Morum. Liber secundus." 


\section{TROUBLE IN PARADISE}

the leader of the Diggers, Gerrard Winstanley, makes a series of legislative proposals for a radically egalitarian post-revolutionary polity that clearly view the dramatic events of the 1640s and 1650s and the Regicide, not in terms of difference, as what we might term an epistemological break, but as an analogue to past events. "God hath honoured you," writes Winstanley in his opening epistle to Oliver Cromwell, "with the highest honour of any man since Moses's time, to be the head of a people who have cast out an oppressing Pharaoh. For when the Norman power had conquered our forefathers, he took the free use of our English ground from them, and made them his servants. And God hath made you a successful instrument to cast out that conqueror, and to recover our land and liberties again" (523). Not for nothing, it seems, is the alternative title of his text, which calls for the levelling of sovereignty on a psychological, social and metaphysical level through common ownership and tilling of the land, True Majesty Restored. For Winstanley, Cromwell was quite literally the new Moses. History was pregnant with utopian possibility and the brave new world of the Commonwealth was nothing other than the fulfilment of what had been promised to the Israelites. ${ }^{2}$

Indeed, arguably the most common plot device in utopian fiction as a whole also seems to hail from Exodus: namely, the fortunate shipwreck. For instance, the heroine of Margaret Cavendish's The Discovery of the New World Called The Blazing World (1666) finds herself alone on uncharted seas (after her kidnappers have frozen to death), where she is discovered by the inhabitants of a new world, talking animals, who take her to their emperor, whom she eventually marries (2-3); after this she debates at length with these animals about their systems of law, sovereignty, and, most importantly, the different areas of knowledge pursued by the various creatures. The trope of the fortunate shipwreck, rendered in the most perfunctory way possible by Cavendish, recalls — perhaps unconsciously - the equally unlikely narrative about the infant Moses in Exodus (2.1-10). This trope recurs twice in The Isle of Pines and a host of other texts that would come to be known as Robinsonades. Moses's mother puts him in a rudimentary raft of rushes and floats him down the Nile and rather than being eaten by crocodiles or simply drowned, the abandoned boy is discovered by the Pharaoh's daughter and is subsequently brought up in the royal household, despite her father's eugenic edict, ordering the murder of the first-born male

2 With extensive reference to Daniel, Antonis Liakos provides a cogent account of the relationship between "the role of history within imagined utopian societies, and the place of utopia in the background of historical thinking" (20) in a special edition of Historein, devoted to history and utopia. 
children of the Israelites to hinder their proliferation $(K \mathcal{J} V$, Exodus 1.16).

This particular similarity points to a more general one between biblical narratives and utopias, which is that they call for a certain suspension of disbelief, a suspension of disbelief that enables history in its original etymological sense - it comes from

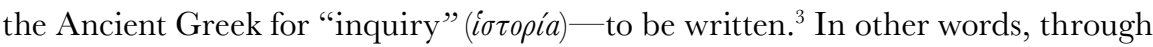
a series of improbable events, a hypothetical situation is constructed, which enables inquiry into complex topics, such as the fraught relationship between law, idolatry and sovereignty, for whether the events such narratives record are plausible or practicable is almost beside the point. Rather, what matters is the ways in which such situations tell us about the institutions, discourses, and ideas of our own world. Ultimately, texts that inquire demand inquisitive readers and the pamphlet form in which the Isle was originally published likewise demanded readers that were "engaged, critical, and questioning, and - like political actors - accustomed to confronting potentiallydeceptive surface appearances and speakers" (Stillman 151-152), readers that would consider the first ruler of the Isle of Pines, who is pathologically incapable of selfreflection, a profoundly disturbing sovereign, even of an imaginary land.

Written by a republican in exile after the Restoration and published in 1668 under the pseudonym of Cornelius Van Sloetten, ${ }^{4}$ Henry Neville's succès de scandale offers, as many of its critics have observed (Mahlberg 1-7, Stillman 147-175), a caustic critique of the Stuart regime, which suggests that sensual pleasure is more important to the restored king and his cronies than the national interest. And although its explicit representation of its sovereign designing a new legal system is ostensibly consistent with the utopian genre's fixation on legal matters, this article argues that the shifting ironies occasioned by Neville's engagement with — or, rather, inquiry into - Exodus serve to problematise the possibility of a "law-based utopia" (Avilés 225) by bringing to the surface contradictions that have been tacit in notions of both utopia and paradise since their respective inceptions.

\section{Misbehaviour}

To teach thee that God attributes to place

No sanctitie, if none be thither brought

By men who there frequent, or therein dwell. (Milton, Paradise Lost 836)

3 See $O E D$ "History" n. 1.

4 This probably recalls the word "slut;" Bruce also notes that "[p]ines may be an anagram of 'penis,' 


\section{TROUBLE IN PARADISE}

Framed within the Sloetten's letter, certified by two letters addressed to "a credible person in Covent Garden” (190), the content of George Pine's testimony about his shipwreck on an uninhabited island, which is read to the sailors by his Grandson, the current sovereign, William, recalls Exodus, at least in so far as it relays the story of the population of an ideal country, a land of plenty. After a description of how he systematically and repeatedly impregnated the four women with whom he was shipwrecked, the polyamorous Pine continues to describe how he divided up his enormous family into tribes. While Amy Boesky (155-166) and Stillman (155-157) have convincingly shown that an archetype of Pine was Noah - he too had a rebellious son, Ham - not least because of the Isle's focus on law, it is also necessary to examine its parodic intertextuality with the next book of the Bible, Exodus.

Marrying off half-brothers and sisters, Pine, like any self-respecting Old Testament Patriarch, divides up his kingdom between these tribes, an action which creates territory and, therefore, private property in paradise, while keeping him as supreme ruler over all of the inhabitants. In the ensuing twenty years, this professional "bookkeeper" (Bruce 194) attempts the occasional census and this "numbering [of] his people" (Hardy 102-103) is even illustrated on the original pamphlet's frontispiece, presumably as a key event in the narrative:

\footnotetext{
I summoned them to come to me, that I might number them. Which I did, and found the estimate to contain, in or about the eightieth year of my age, and fifty-ninth of my coming there, in all, of all sorts, one thousand seven hundred eighty and nine. Thus praying God to multiply them, and send them the true light of the gospel, I last of all dismissed them. For being now very old, and my sight decayed, I could not expect to live long. I gave this narration, written with my own hand, to my eldest son, who now lived with me, commanding him to keep it, and if any strangers should come thither by chance. (Bruce 200)
}

Not only does Neville's narrative, like many other utopian narratives and Robinsonades, record the inhabitation and population of a new land by a people whom chance (or fate) has forced out of their original country, but it also offers a satirical history of this island and a genealogy of its people. Astonishingly, rather than attempting to create a legacy of any sort by actively engineering the future of his society, Pine, who seems concerned only with the physical aspects of existence,

but 'pine' also signified 'punishment,' 'suffering' (especially the suffering of hell), and (as a verb) 'to lose one's vitality or vigour,' as well as 'to languish with desire' (as it still does)" (xxxvii, xl). 
simply counts his subjects and then gives up. Indeed, he recurrently emphasises his good physical health and that of his wives and offspring: "none of the children, for all the hardship we put them to, were ever sick" (Bruce 198). And this must surely have seemed truly Arcadian at a time of high infant mortality, as would the cornucopian fruitfulness of the island and his "consorts" (Bruce 197), almost like a return to Eden or a fulfilment of God's promise to the Jews: "I will take sickness away from the midst of thee. There shall nothing cast their young, nor be barren, in thy land" (KJV, Exodus 22.25-26). After all, despite their dire circumstances, "the children of Israel were fruitful, and increased abundantly, and multiplied, and waxed exceeding mighty; and the land was filled with them" (KJV,Exodus 1.7) - like the English stranded in paradise.

It is, however, the very material plentitude of the island and complete lack of legislation that inculcates the lawless lust, for which this text became notorious: "Idleness and a fullness of everything begot in me," writes George, "a desire for enjoying the women . . . and custom taking away shame (there being none but us), we did it more openly, as our lusts gave us liberty" (Bruce 197-198). Without the necessity of working for survival, the islanders live for sensual pleasures alone. And as the population increases, this very sexual licence, which was tabled as a real social possibility by certain radical sects during the Commonwealth period, results in anarchy; as Pine's grandson, William, moralises: "in multitudes disorders will grow, the stronger seeking to oppress the weaker, no tie of religion being strong enough to chain up the depraved nature of mankind" (Bruce 201). This echoes Glaucon's contention in the Republic that humans are naturally unjust and it is only fear of injury from the law that prevents them from murdering, robbing and raping with impunity (Republic, 360e). And even a return to paradise, Neville adds, would not alter this depressing fact.

After dividing the remarkably fertile inhabitants into four tribes, Pine's eldest son's command of law and order completely dissipates, partly due to a lack of religious instruction: "the sense of sin being quite lost in them, they fell to whoredoms, incests, and adultery" (Bruce 201). Without fear of punishment and the sense that they are held accountable to law, the islanders fail to confine themselves within "the bounds of any modesty, but brother and sister lay openly together; those who would not yield to their lewd embraces, were by force ravished, yea, many times endangered of their lives" (Bruce 201). The shift from sexual (im)morality to social chaos that William Pine narrates to the sailors is also found in The Law 


\section{TROUBLE IN PARADISE}

of Freedom's discussion of what constitutes true freedom. "Others [i.e. the Ranters]," observes Winstanley, "say: It is true freedom to have community with all women, and to have liberty to satisfy their lusts and greedy appetites. But this is the freedom of wanton unreasonable beasts, and tends to destruction" (Works 2:528). From this point of view, George Pine's society would have been doomed from the outset precisely because it is without laws to curb the appetites of its strongest member. As Van Sloetten himself observes: "where the hedge of government is once broken down, the most vile bear the greatest rule" (Bruce 207-208).

Eventually, Henry Pine violently suppresses the dissenting factions on the island, the worst of whom is "John Phill, the second son of the Negro-woman" who "proved guilty of divers ravishings and tyrannies committed ... was adjudged guilty of death, and accordingly was thrown down from a high rock into the sea" (Bruce 202). After murdering his own brother in a vigilante-style lynching and summarily pardoning of the other wrong-doers, the island moves towards a much more conservative vision of utopia. After the insurrection, he lays down six laws that are, essentially, condensed versions of Mosaic Law, albeit with some significant differences, and appoints himself, despite the absence of any legal training whatsoever, as another Moses, the supreme judge of his people (see Exodus 18.26):

1. That whosoever should blaspheme or talk irrelevant of the name of God should be put to death.

2. That who should be absent from the monthly assembly to hear the Bible read, without sufficient cause shown to the contrary, should for the first default be kept without any victuals or drink for the space of four days, and if he offend therein again, then to suffer death.

3. That who should force or ravish any maid or woman should be burnt to death, the party so ravished putting fire to the wood that should burn him.

4. Whosoever shall commit adultery, for the first crime the male shall lose his privities, and the woman have her right eye bored out; if after that she was taken again in the act, she should die without mercy.

5. That who so injured his neighbour by laming of his limbs or taking any thing away which he possesseth, shall suffer in the same kind himself by loss of limb; and for defrauding his neighbour, to become servant to him, whilst he had made him double satisfaction.

6. That who should defame or speak evil of the Governor or refuse to come before him on a summons, should receive a punishment by whipping with rods, and afterward be exploded [sic] from the society of the rest of the inhabitants. (Bruce 202-203) 
Paradoxically, when we design a utopia we envisage the house of our dreams, but more often than not end up furnishing it with the same old furniture. Even designs for a perfect society must have laws. A common complaint in early modern utopias is not that laws exist in the first place, but rather that the current legal system is overly complicated, a Babel-like confusion of words which is exploited for profit by lawyers and judges, breeding corruption and injustice. Given, however, that the Isle is, once again, on the brink of anarchy until the Dutch sailors lend their firepower to Pine's grandson to quell a second uprising, it is clear that Henry's nostalgic return to Old Testament Law is woefully inadequate for maintaining a peaceful society - as it is in Exodus itself, for the Israelites break God's Law by committing idolatry and face obliteration as a consequence.

Related to this is the idea expressed that the legal system of this world is overly harsh; even taking its complex structural ironies into account, More's Utopia remains a design of a racially homogenous and fairly authoritarian society, characterised by the existence of a slave class, continual surveillance and draconian limits on freedom of expression and movement. Nonetheless, in the First Book, Hylothoday, impressed by the utopian legal system, explicitly argues against capital punishment for theft, pointing out that in addition to being corrupt and otiose, such laws are far harsher than the "ungentle and sharp" (Bruce 26) Laws of Moses, for these "punished theft by the purse, and not with death," yet were "given to bondmen, yea, and them very obstinate, stubborn, and stiff-necked" and written long before "the new law of clemency and mercy" (Bruce 26). ${ }^{5}$ Henry's laws are, in contrast, somewhat stricter than those of Moses.

It is no exaggeration to claim that on the Isle of Pines, the rule of law is decidedly dystopian. While some of Henry's proscriptions reflect the common early modern punishments for crimes against property and person, others are even harsher than those criticised by the relatively illiberal Hylothoday. Rather than the dubious

5 The term "stiff-necked" is added to the original text by More's first English translator, Robinson, presumably to emphasise the intransigence of the Israelites, but this term would subsequently come to be used in the Geneva Bible (1599) and the King fames Bible (1611) to describe the stubborn persistence of idolatrous practices among the Jews (e.g. $K \mathcal{F} V$, Exodus 33.5); it is a mirror translation from the Vulgate's "Dixitque Dominus ad Moysen: Loquere filiis Israel: Populus durae cervicis es: semel ascendam in medio tui, et delebo te. Jam nunc depone ornatum tuum, ut sciam quid faciam tibi" (Exodus 33.5, emphasis added). More's original reads simply: "Denique lex Mosaica, quanquam inclemens et aspera (nempe in seruos, et quidem obstinates, lata), tainen pecunia furtum haud morte mulctauit" (Fronde 62-63). 


\section{TROUBLE IN PARADISE}

logic of revenge, characteristic of Old Testament Law - the logic of "eye for an eye" (KJV, Exodus 21.26-27) - Pine's laws are over the top. Transgressions are punished spectacularly and excessively. The punishment for rape, for instance, is being burnt alive with "the party so ravished putting fire to the wood that should burn him" whereas - rather nauseatingly — in the Old Testament the offender may either marry the victim or compensate her father at the going "bride price" (Exodus 22.17). ${ }^{6}$ In Exodus, one is accountable for the sin of blasphemy at the end of time — "the Lord will not hold him guiltless that taketh his name in vain" (22.7) — but on the Isle it is punished by death. Likewise, no punishment for breaking the Sabbath is detailed in Exodus and while it once suggests that one should follow the advice of parents and elders, Exodus neither specifies the punishment for not doing so, nor does it contend that one should be entirely beholden to earthly authority.

In fact, in the state of exception or anomia (åvouía) with which Exodus opens, in which the Pharaoh has ordered the death of the first-born males, the only possible option is to ignore earthly law: Moses's mother and the midwives side-step the unjust command of a tyrant and the flight of the Jews from Egypt is itself an act of civil disobedience, a refusal to believe in the absolute authority of an unjust governor. Tellingly, moreover, the commandment that is most conspicuously absent from Pine's prohibitions is the one that is most recurrent in the Old Testament: the injunction against idolatry $\left(K \mathcal{F}\right.$, Exodus 20.4-5). ${ }^{7}$ And it is hard not to interpret this absence-especially given the fact that Pine assumes sovereignty and breaks the Old Testament rules against pre-marital sex and polygamy $(K \mathcal{J} V$, Exodus 22.17) — as a thinly veiled critique of the dissolute rule of the recently restored Charles II, who was, likewise, the head of the church and judiciary on his island.

Pine, after all, even describes the four women with whom he arrives on the island as his "consorts" and while this might simply serve to characterise him as upwardly mobile (Stillman 163-164), it should not be forgotten that the word "consort" was used specifically to describe "[a] partner in wedded or parental relations" and is usually "[u]sed in collocation with some titles, as queen-consort, the wife of a king" (and is, for this reason, very seldom used in the plural); as a verb, it did not always simply mean "to accompany" but also held overt sexual connotations, as it does to this day. ${ }^{8}$ This ambiguity perhaps serves to help foreground what Stillman describes

6 See also Deuteronomy 22.28-29.

7 See also Ezekiel 6.1-5; Deuteronomy 4.15-31 and 12.29-32.

8 Cf. OED consort $\mathrm{n}$. definitions 1 and 3 ; consort $\mathrm{v}$. definition 2. 
as the "sharp contrast between George's sexual potency as a father in peopling his island and his impotence as a statesman in organising his people" and clearly offers an implicit "critique of England's current and future monarchs" (165).

This, in turn, implicitly links Charles II's notorious sexual licence with idolatry. And as David Hawkes has shown, such licence is considered a form of idolatry, for "the pursuit of fleshly pleasures . . . indicates a misconstrual of the telos of the human being. To be carnal is to forget that the body is a means to a spiritual end" (58). In other words, lechery means delighting in the visible and objective world (the old furniture) at the expense of spiritual and invisible (the new house). Perhaps this is why Pine's decidedly one-dimensional embedded narrative focuses, both in his self-presentation and his representation of his relationships with others, entirely on objective facts, rather than reflecting on what he (or the people with whom he had relationships) thought or felt. Certainly, absolutist monarchs like the Stuarts and the Pines not only demanded a form of veneration that verged on idolatrous because they consider themselves "[t]he deputy elected by the Lord" (Richard II 3.2.53), but also total allegiance, in spite of the fact that Exodus itself clearly implies that such unconditional faith is due to God alone.

\section{Disbelief}

In the history of the island that Pine's grandson narrates, the gulf between what could have been and what actually happened is vast. Although the islanders could have lived without alienation from nature and their own labour and could have fashioned a radically egalitarian new society - just as the Radical sects who met with the Grandees at the Putney Debates in 1647 sought to do - Pine retains a monarchical system of government, in which the head of state is also the supreme judge and chief spiritual leader. For Stillman, the rebellions on the Isle are in the main part caused by the simple fact that the inhabitants do not feel themselves to be enfranchised "citizens" (159), but merely subjects. "George's familial relations," he adds drolly, "represent the Utopia of a patriarchal accountant" (155).

Certainly, the grubbiest piece of furniture left over from the Old World is the segregation of the black inhabitants of the island and the murder of John Phill, events that have, naturally, received considerable critical attention (see Jakka 220-222; Stillman 163-165; Boesky 162-171). Although these actions and the way in which the "depravities of the Phills," who are the cause of both insurrections, "are ascribed 


\title{
TROUBLE IN PARADISE
}

to racial mixing" (Jakka 220) and have been contextualised within the Stuart legislation for maintaining racial purity in the colonies (Boesky), it is worth recalling what Exodus has to say about this subject, particularly given its emphasis on the punishment for idolatry. God's promise to the Israelites is the following:

\begin{abstract}
I will drive out before thee the Amorite, and the Canaanite, and the Hittite, and the Perizzite, and the Hivite, and the Jebusite. Take heed to thyself, lest thou make a covenant with the inhabitants of the land whither thou goest, lest it be for a snare in the midst of thee: but ye shall destroy their altars, break their images, and cut down their groves: for thou shalt worship no other god: for the Lord, whose name is Jealous, is a jealous God. (KJV, Exodus 34.11-14)
\end{abstract}

In both texts, the racial Other is driven out. In Neville, this is because the mixedrace inhabitants of the island revert to savagery without the direct rule of a white Christian man, whereas in the Old Testament the other tribes must be driven out from the promised land because of their adherence to idolatrous practices. Crucially, however, the Jews are the chosen people not because they are intrinsically morally superior to the pagans, but because God and Moses establish strict concordance, governing their lives and religious practices. "There must be suitable Laws," wrote Winstanley in his design for a post-revolutionary polity, "for every occasion, and almost for every action that men do" (Works 2:528). With enough legislation, it seems, utopia can indeed be reached in this world.

Pine's initial response to the island is that "this place, had it the culture that skilful people might bestow on it, would prove a paradise" (197) can only be interpreted as a witheringly ironic characterisation of this quintessent embodiment of homo economicus. This accountant is unable to conceive of a world without labour - he even describes his polyamorous relations with the women more in terms of his methodology for the fertilisation of his "consorts" than sensual pleasures. Crucially, moreover, he fails to realise that paradise cannot be improved by culture, for it is per definition already perfect.

The word "paradise" actually hails from the Old Iranian (via Ancient Greek) word for "enclosure" and the purpose of an enclosure is, of course, to keep some people (or animals) in and others out. In this respect, Paradise has always been exclusive. The Promised Land is not, after all, promised to all, but only to the law-abiding

9 My thanks to Professor Miklós Péti of KRE for pointing this out to me in connection to Paradise Lost. The $O E D$ provides a detailed etymology of the word. 
Israelites and such a land remains a beguiling concept precisely because we are outside of it. George's odd comment is later echoed by Van Sloetten, who, during his survey of the island, observes that "had but nature the benefit of art added unto it, it would equal, if not exceed, many of our European countries" (Bruce 205). Once again, this appears to be somewhat ironic, since the European inhabitants of the island - like most English expats - are decidedly artless. Despite the astonishing abundance of their location, they retain only the most basic form of culture: they do not cultivate the land, remain illiterate, but do have a form of country dancing and, of course, Henry's six rules for life.

The problem remains, however, that the genocides of the twentieth-century - nearly all of which were, to some extent, committed in the name of one utopian ideology or another - were not abhorrent perversions of the utopian ideal, but have been a constitutive feature of this very ideal since its inception in Exodus. This fact rather begs the question: should we strive after utopia? And this pressing question, with which Neville himself seems profoundly engaged, is best answered by recourse to the great philosopher of utopias, Ernst Bloch, who observes in a debate with his friend and colleague, T. W. Adorno, that the "essential function of utopia is the critique of what is present" (12). As the presentation of a series of measures for a better (or even perfect) society, The Isle of Pines - in contrast to The Law of Freedom is clearly intended to be taken with a very large pinch of salt. Rather, its latent utopian potential lies in the way it offers an ironic parable of how paradise is all too easily lost - especially if we fall back on the old order of things. Indeed, it is precisely because of its disenchanted standpoint, forged through its ironic engagement with Exodus, that The Isle of Pines can be said to display the basic utopian drive for an alternative reality. Utopian thought, responds Adorno to Bloch's observation, lies "essentially in the determinate negation [bestimmte Negation] of that which merely is and, by concretising itself as something false, it always points at the same time to what should be" (12).

By offering an inquiry into the relationship between idolatry and tyranny, The Isle of Pines critiques "what is" - i.e. Restoration England. Yet what is still more significant is the ways in which this text's parodic intertextuality with Exodus demonstrates the dangers inherent in this ur-text utopian thought; leaving aside, for a moment, explicit designs for a happier society, many day-dreams themselves have a dangerously utopian structure. For instance, a militant vegan's hope that might be something along the lines of "in an ideal world there would be no omnivorous 


\section{TROUBLE IN PARADISE}

humans" is not so terribly different from the idea that "in an ideal Israel there will be no Amorites." And while undoubtably utopian, such ideas are also exclusive because they are predicated on the eradication (or, at least, the conversion) of a particular group.

The kind of negation to which Bloch and Adorno refer is "determinate," by which they mean it does not offer merely a denial of reality, but a form of negation that depicts aspects of reality, in order to open up the possibility of an alternative and, therefore, hold at arm's length the limitations of this world. The Isle of Pines, after all, is testament to the unfortunate fact that it is all but impossible to conceive - at least, in practical terms - of a completely new world-order, free from oppression, alienation and pain. Nonetheless, the notion that we should simply assume that "what is present" is the best of all possible worlds offers a form of quietism that is abhorrently uncritical. Without a doubt, it is the unlikely or even seemingly impossible hope that things could be other than how they are that effects real social change - be it the Arab Spring or the Civil Rights movement in the U.S. For these reasons, it is necessary to suspend our disbelief in utopia, but this does not necessarily mean we should forget that utopia too has a history.

\section{Works Gited}

Avilés, Miguel Angel Ramiro Avilés. "The Law-Based Utopia." Critical Review of International Social and Political Philosophy 3.2-3 (2000): 225-248.

Biblia Sacra Vulgata: Holy Bible in Latin. Eds. Gryson, Roger et al. Peabody, MA: Hendrickson, 1994.

The Bible: Authorised King James Version with Apocrypha. Eds. Carroll, Robert, and Stephen Prickett. Oxford: Oxford University Press, 1997.

Bloch, Ernst, and Adorno T. W. "Something is Missing: A Discussion between Ernst Bloch and T. W. Adorno on the Contradictions of Utopian Longing." In The Utopian Function of Art and Literature. Trans. Jack Zipes. Cambridge, MA: MIT Press, 1983. 1-17.

Boesky Amy. "Nation, Miscegenation: Membering Utopia in Henry Neville's The Isle of Pines." Texas Studies in Literature and Language 37.2 (1995): 165-184.

Bruce, Susan, ed. Three Early Modern Utopias: Utopia, The New Atlantis and The Isle of Pines. Oxford: Oxford University Press, 2008. 
Cavendish, Margaret. The Description of the New World Called the Blazing World. London: A. Maxwell, 1666.

Davis, J. C. "Utopia and history." Australian Historical Studies 13.50 (1968): 165-176. Hardy, Nat. "Euphemizing Utopia: Repressing Sex and Violence in The Isle of Pines' Frontispiece." Utopian Studies 17.1 (2006): 99-107.

Hawkes, David. Idols of the Marketplace: Idolatry and Commodity Fetishism in English Literature, 1580-1680. New York: Palgrave, 2001.

Jakka, Sarath. "Fictive Possessions: English Utopian Writing and the Colonial Promotion of Madagascar as the 'Greatest Island in the World."” 2018. University of Kent/Porto, unpublished PhD dissertation.

Liakos, Antonis. "Utopian and Historical Thinking: Interplays and Transferences." Historein 7.1 (2007): 20-57.

Mahlberg, Gaby. Henry Neville and English Republican Culture in the Seventeenth-Century: Dreaming of Another Game. Manchester: Manchester University Press, 2009.

Milton, John. The Riverside Milton. Ed. Flanagan, Roy. New York: Cengage, 1998. More, Thomas. The Utopia of Thomas More in English and Latin. Ed. Fronde, J. A. London: Oxford University Press, 1895.

Plato. Republic. Trans. Paul Shorley. Loeb Classical Library, 237. Cambridge, MA: Harvard University Press, 1930.

Shakespeare, William. The Norton Shakespeare. Eds. Greenblatt, S., W. Cohen, J. Howard, and K. Eisaman Maus. New York: Norton, 1997.

Stillman, Peter. "Monarchy, Disorder, and Politics in The Isle of Pines." Utopian Studies 17.1 (2006): 147-175.

Vonnegut, Kurt. Slaughter House Five: The Children's Crusade: A Duty Dance with Death. New York: Dial Press, 2009.

Wells, H.G. A Modern Utopia. Eds. Claeys, Gregory, and Patrick Parrinder. Harmondsworth: Penguin, 2006.

Winstanley, Gerrard. The Complete Works of Gerrard Winstanley. Vol. 2. Eds. Corns, Thomas N., Ann Hughes, and David Loewenstein. Oxford: Oxford University Press, 2009.

\section{Contributor Details}

Sam Gilchrist Hall is a Senior Lecturer in English at Károli Gáspár University of the Reformed Church in Hungary and an Honorary Research Fellow 


\section{TROUBLE IN PARADISE}

of Kingston University, London. His main research interest lies in conceptualisations of dwelling and belonging in medieval and early modern texts. He was educated at the University of London and has published a monograph, Shakespeare's Folly: Philosophy, Humanism, Critical Theory (Routledge, 2016), and several articles on early modern literature and critical theory. 